J. Clin. Chem. Clin. Biochem.

Vol. 17, 1979, pp. 505-511

\title{
New Developments in the Diagnosis of Cerebrospinal Fluid
}

Report on the workshop conference

of the German Society for Clinical Chemistry

held on October 13-14, 1978

in Marburg/Lahn, Universitäts-Nervenklinik

\section{By T. O. Kleine}

(Received March 27, 1979)

\section{Participants:}

D. Büchsenschütz, Fa. Travenol GmbH, Nymphenburger Str. 1, D-8000 München 1

Dr. $R$. Dörries, Institut f. Virologie und Immunbiologie der Universität, Versbacher Landstr. 7, D-7800 Würzburg

Dr. K. Eickhoff, Liesegangstr. 15, D-4000 Düsseldorf 1

Priv. Doz. Dr. P. Engelhardt, Medizinische Hochschule Hannover, Neurologische Klinik und Poliklinik, Karl-Wiechert-Allee 9, D-3000 Hannover 61

Prof. Dr. K. Felgenhauer, Universitäts-Nervenklinik, Neurologisch-psychiatrische Forschungsabteilung, Joseph-StelzmannStraße 9, D-5000 Köln

Prof. Dr. H. Glasner, Universitäts-Nervenklinik, D-6650 Homburg/Saar

Priv. Doz. Dr. A. M. Gressner, Klinisch-Chemisches Zentrallaboratorium, Goethestraße 27, D-5100 Aachen

Prof. Dr. Dr. K. Hempel, Institut für Med. Strahlenkunde der Universität Würzburg, Versbacher Landstr. 5, D-8700 Würzburg

Dr. H. Hobler, Universitäts-Frauenklinik, D-8700 Würzburg

Dr. D. Karcher, Born-Bunge Stichting, Universitaire Instelling Antwerpen, Belgium

Dr. P. Kaufmañn, Institute of Neurology, Queen Square, University of London WC $1 \mathrm{~N} 3 \mathrm{BG}$

Prof. Dr. T. O. Kleine, Universitäts-Nervenklinik, Klinischchemisches Labor, Ortenbergstr. 8, D-3550 Marburg/Lahn

Prof. Dr. E. Ch. Laterre, Cliniques Univer sitaires St. Luc, B-1200 Bruxelles, Belgium

Prof. Dr. A. Lowenthal, Born-Bunge Stichting, Universitaire Instelling Antwerpen, Belgium

Prof. Dr. F. Müller, Hygiene-Institut, Serologische Abteilung Gorch-Fock-Wall 15/17, D-2000 Hamburg 36

Dr. O. Müller-Plathé, Allgemèinés Krankenhaus Altona, Zentrallaboratorium, Paul Ehrlich Str. 1, D-2000 Hamburg. 50

M. Noppe, Born-Bunge Stichting, Universitaire Instelling Antwerpen, Belgium

Dr. E. Peheim, Chemisches Zentrallabor, Inselspital, Bern, CH-3010 Bern, Schweiz

Dr. K. W. Pflughaupt, Neurologische Universitäts-Klinik u. Poliklinik im Kopfklinikum, Josef-Schneider-Str. 11, D=8700 Würzburg
Dipl-Ing. Dr. P. Riederer, Ludwig-Boltzmann-Institut $\mathrm{f}$. Klin. Neurologie, Wolkersbergenstr. 1, A-1130 Wien, Österreich

Dr. G. K. Schlenska, Universitäts-Nervenklinik, Ortenbergstr. 8 , D-3550 Marburg/Lahn

Dr. G. Schliep, Universitäts-Nervenklinik, Neurolog isch-psychiatrische Forschungsabteilung, Joseph-Stelzmann-Str. 9 , D-5000 Köln

Dr. B. Schmidt, Ludwig-Boltzmann Institut $\mathrm{f}$. Dermato-Venerologische Serodiagnostik, Wolkersbergenstr. 1, A-1130 Wien, Österreich

Dr. Schümann, Zentrallaboratorium, Städt. Krankenhaus, D-3500 Kassel

Dr. Dipl.-biochem. R. Seuffer, Doblerstraße 11, D-7400 Tübingen

Dr. A. Sieber, Fa. Behringwerke AG, Postfach 1140, D-3550 Marburg/Lahn

M. Simon, Neurologische Klinik der Universität, Langenbeckstr. 1, D-6500 Mainz

Prof. Dr. Dr. D. Stamm, Max-Planck-Institut f. Psychiatrie, Abteilung für Klinische Chemie, Kraepelinstr. 10, D-8000 München 40

Dr. Th. Stamm, Medizinische Hochschule Hannover, Neurologische Klinik und Poliklinik, Karl-Wiechert-Allee 9, D-3000 Hannover 61

Prof. Dr. H. Vahar-Matiar, Universitäts-Nervenklinik, Abtlg. für Liquorphysiologie und klinische Neurochemie, Annaberger Weg, D-5300 Bonn-Venusberg

Dr. $M$. Weber, Städt. Krankenhaus, Neurologische Klinik, Theodor-Kutzer-Ufer, D-6800 Mannheim

Priv. Doz. Dr. B. Weisner, Universitäts-Krankenhaus Eppendorf, Neurologische Klinik, Martinistr. 52, D-2000 Hamburg 20

Dr. $R$. Weiss, Ludwig-Boltzmann-Institut f. klin. Neurobiologie, Wolkersbergenstr. 1, A-1130 Wien, Österreich

Prof. Dr. V. Wieczorek, Klinik und Poliklinik f. Neurologie u. Psychiatrie, Friedrich-Schiller-Universität, Philosopheniveg 3, DDR-69 Jena

Dr. H. Wiethölter, Institut f. Hirnforschung der Universität, Calwer Str. 3, D-7400 Tübingen 1

Dr. W. Tritschler, Fa. Boehringer Mannheim GmbH, Postfach 310120 D-6800 Mannheim 31

\section{Organisation: T. O. Kleine, Marburg/Lahn}

The main question considered by the workshop was: which new methods for the diagnosis of CSF are now available and suitable for the diagnosis of nervous diseases? The methods are presented in three topics:

Topic A: Specific methods for the detection of proteins in CSF.

Topic B: Determination of metabolites and electrolytes in CSF.

Topic C: Counting and differentiation of cells in CSF.

At the end of the inventory list, recommendations are made for the laboratory investigation of CSF. 
Neue Entwicklungen in der Diagnostik des Liquor cerebrospinalis

Bericht über die Kleinkonferenz

der Deutschen Gesellschaft für Klinische Chemie

am 13. und 14. Oktober 1978

in Marburg/Lahn, Universitäts-Nervenklinik

Das Hauptthema der Kleinkonferenz war: Welche neuen Methoden für die Liquordiagnostik sind heute verfugbar und anwendbar für die Diagnostik neurologischer Krankheiten? Die Methoden werden in drei Abschnitten zusammengefaßt dargestellt:

A: Spezifische Methoden zur Messung von Proteinen im Liquor.

B: Bestimmung von Metaboliten und Elektrolyten im Liquor.

C: Zählung und Differenzierung der Zellen im Liquor.

Am Ende der Auflistung werden Empfehlungen für die Liquoruntersuchung im Labor gegeben.

\section{Specific Methods for the Detection of Proteins in CSF}

Two site immunoradiometric assay for the determination of $\alpha$-albumin (glial fibrillary acidic protein)

\section{Noppe, D. Karcher, A. Lowenthal and J. Gheuens}

$\alpha$-albumin (1) is a specific marker for glial cells (2). In a 2-site immunoradiometric assay, $\alpha$-albumin reacts with cellulose $\mathrm{CNBr}$ coupled antibodies. After a washing step this insoluble complex is incubated with ${ }^{125} \mathrm{I}$ labelled antibodies. The bound radioactivity is proportional to the concentration of $\alpha$-albumin. $10.3 \%$ of the cerebrospinal fluids have measurable amounts of $\alpha$-albumin. $\alpha$-albumin is found in CSF of patients affected by poisons, multiple sclerosis (M.S.), and mainly epilepsy. The presence of $\alpha$-albumin in cerebrospinal fluid can indicate acute brain damage.

Radioimmunoassays for the determination of myelin basic proteins (MBP)

\section{K. Hempel, D. Dommasch and W. Brors}

Myelin from the central nervous system (CNS) and from the peripheral nervous system (PNS) share at least one basic protein (A1 protein, $M_{\mathrm{r}} 16000$ Dalton). PNS myelin contains a second basic protein ( $\mathrm{P} 2$ protein, $M_{\mathrm{r}} 12000$ Dalton). Antibodies against $\mathrm{A} 1$ and $\mathrm{P} 2$ do not cross-react and were used to establish radioimmunoassays for A1 and P2 in CSF. A1 level was markedly increased in demyelinating diseases especially in exacerbation of M.S.

Comparative studies of lysozyme in native CSF by antigen-antibody nephelometry and substrate degradation

\section{T. O. Kleine, L. Chang and G. Röhner}

Human lysozyme was determined in CSF, by using a specific antiserum (from Behringwerke) with nephelometric end point assay ( $2 \mathrm{~h}, 50 \mu \mathrm{l}$ sample in $225 \mu \mathrm{l}$ reaction mixture with $35 \mathrm{~g} / 1$ polyethylene glycol (PEG)) or the specific degradation of bacterial cell wall (Test-combination Properzym, from Behringwerke, Marburg/Lahn). The range lay between 0.005 to 0.008 $\mathrm{g} / 1$ for both methods; recovery was $103 \pm 6 \%$.

In 17 samples of CSF there was only a partial agreement between the two methods, because $50 \%$ of the samples appeared to contain some unknown interference. Elevated lysozyme levels were found in bacterial and abacterial meningitis, M.S., polyradiculitis, cerebral tumours and lumbar syndromes.

Detection of antiviral antibodies in cerebrospinal fluid by means of a solid phase radioimmuno. assay

\section{R. Dörries and V. ter Meulen}

With the use of radioimmunoassays (RIA) it is now possible to measure the total amount of antiviral antibody (AAB). In the indirect solid phase $\mathrm{AAB}$ from CSF, or a serum sample, binds specifically to viral antigen conjugated to polystyrene microtiter wells. Bound antibody (AB) is then monitored directly by addition of iodinated $\left({ }^{125} \mathrm{I}\right)$ anti-immunoglobulin $(\mathrm{Ig}) \mathrm{AB}$. This technique makes it possible to differentiate between virus-specific Ig classes, by using heavy chain specific radioactive labeled anti-Ig-AB. The detection and differentiation of antiviral $\operatorname{IgG}$ and $\operatorname{IgM} A B$ is possible even in CSF specimens with minor quantities of $\mathrm{AB}$. Generally, the detection of virus specific $A B$ may done with blood serum, because of the higher concentration of $T$. and B-lymphocytes.

Demonstration and origin of Treponema-specific antibodies in cerebrospinal fluid

\section{F. Müller}

Investigations on the titre of treponema-specific antibodies (TSA) in serum and CSF specimen of the same test person have been made $(3,4)$. They have shown that in nearly every case the antibody titre of the CSF is less than $1 / 100$ of the serum titre. This correlation is neither in relationship to pleocytosis nor to total protein increase in the CSF and it does not participate 
in clinical signs of CNS infection. There is evidence that TSA has been transferred from serum to CSF by activity of the blood-brain-barrier. Negative antibody findings in CSF may indicate that a participation of CNS on the treponemal infection is very unlikely.

\section{The diagnostic relevance of single protein levels} in CSF

\section{K. Felgenhouer and G. Schliep}

The steady state equilibrium between the serum and the CSF compartment is impaired in numerous diseases of the CNS $(5,6)$. A "barrier disturbance" is caused either by an increased permeability of the barrier structures (meningitis type) or a reduced CSF turnover (tumour type). Decreased serum/CSF concentration ratios of the marker proteins (e.g. albumin, ceruloplasmin, $\alpha_{2^{-}}$ macroglobulin) are found in acute inflammatory states of CNS in lesions that impair the CSF circulation (e.g. cervical and lumbal disc herniations, tumours, cysts, arachnitic scars), in encephalomalacia and in some degenerative diseases (amyotrophic lateral sclerosis, Parkinson disease, Huntington chorea). A cellular immune response dominates all acute inflammatory states; a secretory immunoglobulin fraction may be the only parameter for subacute or chronic inflammatory conditions, e.g. subacute sclerosing panencephalitis, neurolues, M.S. and herpes encephalitis.

Determination of immunoglobulin (Ig) concentrations in CSF on the basis of their light-chain antigenic properties

\section{K. Eickhoff, R. Heipertz and W. Kaschka}

The concentrations of Ig type $\kappa$ and $\lambda$ and the $\kappa / \lambda$ ratio are determined in the sera and CSF of normal controls as well as patients with inflammatory CNS disease, M.S. and other neurological diseases by radial immunodiffusion (7-9). Both inflammatory disease of the CNS and M.S. are associated with a relative increase of Ig-k expressed as a significant shift in the $\kappa / \lambda$ ratio. Statistical evaluation of the validity and specificity of the $\kappa / \lambda$ ratio as a parameter to differentiate M.S. from other neurological diseases showed that $25 \%$ false negative and $39 \%$ false positive results could be expected. An altered $k / \lambda$ ratio in CSF is therefore not specific for M.S., but the determination of Ig- $\kappa$ and Ig- $\lambda$ in CSF is useful as an additional parameter for the evaluation of the immunological reaction within the CNS.

\section{Determination of prealbumin in cerebrospinal} fluid

\section{B. Weisner}

An electroimmuno assay is used for the determination of prealbumin (cf. l.c. (10)). The agarose, monospecific antiserum against prealbumin and standard human serum are from Behringwerke Marburg/L. Prealbumin concentrations in ventricular and lumbar CSF from reference persons exhibited a near "Gaussian" distribution. Arithmetical means and standard deviations: lumbar CSF $\bar{x}=17 \mathrm{mg} / 1, \mathrm{~s}=3 \mathrm{mg} / 1$; ventricular CSF $\bar{x}=18 \mathrm{mg} / \mathrm{l}, \mathrm{s}=3 \mathrm{mg} / \mathrm{l}$; serum $\bar{x}=263 \mathrm{mg} / \mathrm{l}, \mathrm{s}=65 \mathrm{mg} / 1$. Prealbumin can be used as an indicator of CSF production and circulation. In patients with a stop in the spinal flow of CSF, prealbumin concentration is reduced in lumbar CSF. The same phenomenon is observed in patients with a reflux of CSF into the ventricles (hydrocephalus malresorptivus). The findings indicate that this protein is added to CSF in the ventricles only.

Determination of prealbumin in CSF by antigenantibody nephelometric assay and by quantitative electrophoresis

\section{T. O. Kleine and B. Merten}

Prealbumin was determined in CSF by the nephelometric assay of its specific antigen-antibody complex, using the Behring Nephelometer (11). The laser assay was calibrated by radialimmunoassay (M-Partigen plates, Behring-Werke, Marburg/Lahn). Prealbumin was also determined in CSF by quantitative electrophoresis on cellulose acetate sheets (cf. 1.c. (12)). Relative staining intensities of the protein bands were corrected assuming prealbumin to have the same binding capacities of stain as albumin (cf. 12). The values obtained by both procedures do not differ for lumbar liquores having a total protein content of $\leqslant 0.45 \mathrm{~g} / 1$; with $>0.45 \mathrm{~g} / 1$ significantly higher values for prealbumin were found than those measured by nephelometric assay. Only nephelometric assay appears to be reliable and sensitive for the prealbumin determination in CSF.

Comparative studies of IgG determination with three nephelometric and two turbidimetric assays in $\mathrm{CSF}$

\section{T. O. Kleine and B. Merten}

IgG was determined in samples $(n=40-80)$ of CSF by

A: $(1 \mathrm{~h})$ using antiserum, standards and nephelometer from Hyland-Travenol (München);

B: $(1 \mathrm{~h})$ with forward laser scattering using $\mathrm{LN}$-antiserum, LN-standards and nephelometer from Behringwerke (Marburg/Lahn), (cf. 1.c. (11));

C: rate nephelometric analysis with laser scattering using monospecific antiserum, standards and Immunochemistry Analyzer from Beckman (München);

D: turbidimetric end point analysis $(20 \mathrm{~min})$ at $336 \mathrm{~nm}$ with microcuvettes $\left(25^{\circ} \mathrm{C}\right.$ ) (Eppendorf 5086) using antiserum and standards from Behringwerke (Marburg/ L.) (cf. 1.c. (11).

$\mathrm{E}$ : same as procedure $\mathrm{D}$ but using kinetic analysis $(0.5$ to $6.0 \mathrm{~min}$ interval). 
All procedures yield the same IgG values in CSF determined with a precision of about $10 \%$ and a sensitivity of 0.004 to $0.010 \mathrm{~g} / \mathrm{lgG}$. The range of the nephelometric assays $(\geqslant 0.25 \mathrm{~g} / \mathrm{l})$ is twice as high as that of turbidimetric assays. The procedures $B, D$ and $E$ need small total volumes; procedure $A$ uses the smallest sample volume; procedures $\mathrm{C}$ and $\mathrm{E}$ are least timeconsuming.

Individual blanks are determined only with procedure $A$, which exhibited an error of 0.005 to $0.022 \mathrm{~g} / 1 \mathrm{IgG}$. The data indicate the importance of individual blanks with nephelometric end point analysis. No unspecific interference of $35 \mathrm{~g} / \mathrm{l}$ polyethylene glycol with procedure $B$ was found.

Protamine optimised laser-nephelometric measurement for IgA in cerebrospinal fluid (CSF)

\section{H. Hobler and $K . \cdot W$. Pflughaupt}

Using a protamine optimised IgA-assay an incubation time of two hours is sufficient: $0.1 \mathrm{ml}$ standard-saline

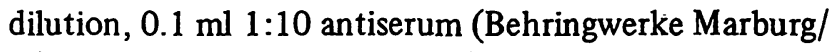
L.)-phosphate buffer ( $40 \mathrm{mmol} / \mathrm{l})$ dilution, $0.1 \mathrm{ml} \mathrm{1:50}$ protamine (1000 Roche) - bidist. water dilution. 100 unselected liquors ranged from 0.3 to $120 \mathrm{mg} / 1$. The correlation of an IgA assay with addition of protamine in contrast to an IgA assay without protamine showed a coefficient of $R^{2}=0.9875$ and a linear regression of $y=0.022+0.9566 x(n=50)$.

Sensitivity for the determination of IgG, IgA, IgM by three commercially available procedures with different antisera and standards

\section{G. K. Schlenska and T. O. Kleine}

Three procedures were used:

A: (1 h) using antisera, standards and nephelometer from Hyland-Travenol (München);

B: nephelometric end point analysis ( $1 \mathrm{~h})$ with $\mathrm{LN}$-antisera, LN-standards and nephelometer from Behringwerke (Marburg/L.);

C: turbidimetric kinetic analysis (1-6 min interval) at $365 \mathrm{~nm}(\mathrm{~d}=1 \mathrm{~cm}) 25^{\circ} \mathrm{C}$, Eppendorf 5086), antisera and standards from Boehringer Mannheim (Tina quant ${ }^{\mathrm{R}}$ ).

Similar results are obtained for IgG by the three procedures comparing sensitivity, upper range of application and precision within series. Nephelometric end point analysis for IgA and IgM is 10 to 50 times less sensitive than nephelometric end point analysis. The three procedures as well as the four standards are comparable for $\mathrm{IgG}$ and IgM, but range of variation is $\pm 15 \%$. Considerable deviations are obtained with procedure $\mathrm{C}$ for IgA. Standardized calibration sera and antisera are necessary for the determination of $\operatorname{Ig}$ (cf. 1.c. (13)).
Partially specific electrophoresis of CSF proteins Summary: The procedures should satisfy two claims:

A: application of small volumes of native, unconcentrated liquor,

B: demonstration of the oligoclonal reaction of immunoglobulins (A. Lowenthal).

Four different procedures were presented which all correspond to claim A:

1. agar gel electrophoresis using 10-15 $\mu \mathrm{l}$ sample and silver staining for the bands (paper presented by $D$. Karcher, A. Lowenthal \& G. van Soom),

2. polyacrylamide gel electrophoresis without stacking gel using $0.5 \mathrm{ml}$ sample, $7.5 \%$ acrylamide and Coomassie Blue or Amidoschwarz for staining (paper presented by $P$. Kaufmann, J. Thompson),

3. microzone electrophoresis $(0.25 \mu \mathrm{l}$ sample) on cellulose acetate films which were scanned quantitatively in the untransparent form after staining with Amidoschwarz (H. Glasner) (cf. 1.c. (14)),

4. electrophoresis on cellogel strips using $175 \mu$ sample, Amidoschwarz for staining and the transparent strip for quantitative scanning (paper presented by $H$. Koppel, P. Riederer).

Procedures 1,2,4 yield better resolutions of the bands compared to procedure 3. Claim B appears.to be satisfied only with procedures 1,2 , and a modified procedure 3 , a short time microzone electrophoresis (paper presented by $H$. Glasner). The question remains open as to whether any of the electrophoretic procedures is diagnostically equivalent to the simultaneous determination of the concentration of single proteins in CSF and serum and the establishment of concentration ratios.

Crossed immuno electrophoresis on cellulose ace tate membranes with unconcentrated CSF

\section{B. Schmidt}

The procedure of Koppel (cf. 1.c. (15)) has been modified: The area of cellulose acetate membrane and amounts of antisera have been reduced to $1 / 10$ and $1 / 4$, respectively. The molarity of the buffer was decreased by a factor of 2 and its $\mathrm{pH}$ increased to 8.9. The electropherograms were evaluated by a digitizer and a Wang 2200 computer. The error in the tracing the peripheries of rockets is smaller than $2.5 \%$. More than 30 proteins from one CSF sample can be determined quantitatively and qualitatively.

\section{Addendum}

Quantitation of protein adsorbance to glass and plastic tubes: significance for CSF proteins T. O. Kleine and B. Merten

Protein adsorbance to glass and plastic tubes is well known $(16,17)$. To determine the quantity of adsorbed 
proteins in CSF samples, commercially available glass or plastic tubes (e.g. polystyrene, propathene, polycarbonate, high pressure poly thene) and polystyrene LNcuvettes (Sarstedt) were wetted for $15 \mathrm{~min}$ up to their effective area with protein solutions containing human lysozyme; albumin, immunoglobulin IgG and other proteins or CSF. The proteins were determined by a nephelometric end point assay with nephelometer, antisera and standards from Behringwerke (Marburg/L.). The plastic tubes and cuvettes do not adsorb IgG, IgA, albumin and prealbumin from CSF samples, but they adsorb purified proteins. To prevent the adsorption effect no solution of purified proteins should be used without the presence of other proteins; the antigenantibody reaction should be started by adding the sample to the cuvettes.

\section{Determination of Metabolites and Electrolytes in CSF}

Lactate and lactate dehydrogenase activity in lumbar liquor: Diagnostic value

T. O. Kleine, K. Baerlocher, V. Niederer, H. Keller, F. Reutter, W. Tritschler and W. Bablok

Lactate was assayed by a new enzymatic procedure and lactate dehydrogenase activity was measured under optimized conditions (both from Boehringer Mannheim). Reference values $(n=142)$ for lactate concentration (median $1.6 \mathrm{mmol} / \mathrm{l}$ ) and lactate dehydrogenase activity (median $14 \mathrm{U} / 1$ ) were established. The highest lactate concentration found with abacterial meningitis $(n=82)$ lay $\leqslant 3.4 \mathrm{mmol} / \mathrm{l}$, the lowest concentration found with acute bacterial meningitis $(n=33)$ was $\geqslant 3.5 \mathrm{mmol} / \mathrm{l}$. The range of lactate dehydrogenase activity values overlapped, indicating "false positive" values with respect to acute bacterial meningitis (median for acute bacterial meningitis: $52 \mathrm{U} / 1,95 \%$ percentile for abacterial meningitis: $60 \mathrm{U} / 1)$. By taking leucocyte counts $\geqslant 800 / \mu \mathrm{l}$ as the lower limit for acute bacterial meningitis, together with CSF lactate levels $\geqslant 3.5 \mathrm{mmol} / \mathrm{l}$, brain tumours and cerebro-vascular diseases, exhibiting lower leukocyte counts, but partially high lactate values, can be omitted from diagnostic consideration.

\section{Application of an enzymatic procedure for the} determination of cholesterol in CSF

\section{T. O. Kleine and H. Keller}

The cholesterol esterase-, cholesterol oxidase - colour reaction (cf. 1.c. (18)) has been adapted to the conditions of lumbar liquor, using a $100 \mu \mathrm{l}$ sample, $605 \mu \mathrm{l}$ total volume, a blank without cholesterol oxidase, and the Eppendorf Substrate Analyser 5090. The reaction is linear within the range of 13 to $260 \mathrm{nmol}$ cholesterol using test combination and Precilip as standard (both from Boehringer Mannheim). Reference values were established with 125 lumbar liquors: median 0.36 $\mathrm{mmol} / \mathrm{l}$. Increased cholesterol concentrations were found in CSF from patients with spinal tumours, M.S., encephalitis, bacterial meningitis and with different lumbar syndromes.

Lipid electrophoresis of native lumbar liquor on cellulose acetate membranes

\section{T. O. Kleine and Ch. Enders}

Two $\mu$ l of native CSF were used for lipid electrophoresis, applying the conditions of electrophoresis for CSF proteins (cf. 1.c. (12)). The cellulose acetate membrane was fixed with Kunkel's solution and treated with ozone (apparatus from Sartorius Membranfilter, Göttingen). After staining with Schiff's reagent the membrane was scanned with Beckman Jcanner R 112/CDS 100 showing $\beta$ - pre- $\beta$ - and $\alpha$-lipoprotein bands of different intensities with the following cases $(n=10)$ : with bacterial and viral meningitis: pre- $\beta>\beta \geqslant \alpha$, with incomplete transverse section $\alpha>$ pre $\beta=\beta$, meniscus prolapse and intracerebral bleeding $\beta>$ pre- $\beta>\alpha$, subarachnoidal haemorrhage pre- $\beta>\alpha>\beta$. Moreover, up to 6 bands could be detected during the course of a bacterial meningitis indicating a metabolism of lipoproteins in CSF. However, the procedure is insensitive for CSF with a total protein concentration $\leqslant 1.0 \mathrm{~g} / \mathrm{l}$.

Quantitative measurement of CSF electroly tes with special regard to magnesium determined by spectral photometry using atomic absorption

\section{H. Vahar-Matiar}

For the measurement of electrolytes $\left(\mathrm{K}^{+}, \mathrm{Na}^{+}, \mathrm{Ca}^{++}\right.$, $\mathrm{Mg}^{++}, \mathrm{Cl}$ ) in CSF and blood serum photometry (PF 5 Zeiss) and spectral photometry by atomic absorption (Zeiss-FMD) were used under the same conditions. $\mathrm{Cl}^{-}$ content was measured by Eppendorf chloride meter 6610 . Normally, the CSF concentration of $\mathrm{Ca}^{++}$is obtained by halving the value of that in blood serum. CSF- $\mathrm{K}^{+}$versus serum- $\mathrm{K}^{+}$yields the ratio 0.7 ; the $\mathrm{CSF} /$ serum-ratio for $\mathrm{Na}^{+}$is 1.05; for $\mathrm{Mg}^{++} 1.22$; and for $\mathrm{Cl}^{+} 1.13$. A decrease in CSF- $\mathrm{K}^{+}$is found in meningitis and acute brain damage (contusio cerebri), an increase in cases of chronic alcoholism and with adenoma of the hypophysis. During the start of epileptic seizures an increase of $\mathrm{Ca}^{++}$ occurred for about 3 weeks. CSF- $\mathrm{Mg}^{++}$is higher than in serum. With traumatic brain damage, brain tumours and chronic alcoholism $\mathrm{Mg}^{++}$decreases in serum, but it often increases in CSF.

\section{Counting and Differentiation of Cells in CSF}

$S$ tandardization of the cytodiagnosis of the CSF V. Wiczorek

A cy togram of CSF cells should indicate the relative percentage of the following types of cells: lymphocyte- 
like cells, monocyte-like cells, activated monocytes; neutrophilic and eosinophilic leucocytes, plasma celllike cells, lymphoid cells (e.g. large and small basophilic cells); at least 4 types of phagocy tes (erythrophages, hemosiderophages, lipophages, leucophages), giant cells, tumour suspicious cells, tumour cells, leukemia cells; cells from ependym, plexus, arachnoidea; contamination of blood (e.g. artificial, pathological, unknown genesis).

\section{Cell collection from CSF : Comparison of diffe- rent methods}

\section{P. Engelhardt and Th. Stamm}

Our studies of about 20.000 specimens allow a preliminary comparison between sedimentation chamber (19) and millipore filter technique (20): millipore filter technique is the more suitable for routine examinations, especially in CSF samples having a low cell count. The liquor can be used again for examination of non-corpuscular contents. When the number of cells rises, the cell loss increases exponentially. The cells show multiple pseudopods and lie in different optical planes. Only a modified staining of May-GrünwaldGiemsa can be used which is disadvantageous in differentiation of neutrophilic and eosinophilic granulocytes as well as leukemic diseases. The sedimentation chamber technique must be used when recognition of special cell products is wanted, and when cell metabolism or therapy control in tumours are to be investigated by autoradiography. The liquor, however, is lost, and with it an increasing number of cells (up to $50 \%$ lymphocytes). The Sayk's procedure is better suited for interdisciplinary discussions and photographs. A fixation of CSF cells is possible.

The advantage of selective dyes for CSF-cells

\section{P. Engelhardt and Th. Stamm}

The problem of the lack of histological structure of CSF cells can be partly overcome by the use of selective dyes. Normally, the panoptic staining (May-Grünwald-Giemsa) and the knowledge of morphological criteria allow discrimination between benign and malign cells. In general selective dyes only confirm the morphological findings, and they are rarely pathognostically important as in leukemic diseases.

\section{Cytology of CSF using prestained slides T. O. Kleine}

A clear-cut differentiation between neutrophilic leukocytes and mononuclear CSF cells appears to be insufficient with conventional procedures of cell counting and staining (cf. 1.c. (21)) by the Fuchs-Rosenthal chamber. A differentiation under higher magnifications is needed to get good discrimination in the diagnosis of CSF syndromes. For this purpose a new scanning method is developed using prestained slides and $20 \mu$ l native CSF (21), which distinguishes red blood cells and almost all types of leukocytes e.g. lymphocytes and their transformed forms, monocytes, storage cells, segmental neutrophilic and eosinophilic granulocytes. Differentiation predominantly occurs by nuclear pattem. Long counting times are needed for low levels of white blood cells as well as photographic documentation.

Methodological problems with qualitative cerebrospinal fluid cy tology

\section{H. Wiethölter}

Various routine enrichment methods were compared using various criteria. The results of this comparison showed that:

a) simple centrifugation should not be used because of the poor morphologic and quantitative cell acquisition.

b) the membrane filter method (cf. 1.c. (20)) is quick and provides cell-free CSF for subsequent examinations. It can also be used for CSF which has been fixed in formalin. It, however, is not completely satisfactory in terms of the morphology.

c) cell loss with cytocentrifugation is high, and there is considerable artefact formation. The method is quick. Evaluation of the cells undamaged by artefacts is good.

d) the best cytomorphologic results are obtained with the sedimentation method (cf. 1.c. (19)). Although the procedure is time consuming and cell loṣs is high, it is still superior to all other methods.

e) the slide method (cf. 1.c. (21)) cannot serve as a replacement for the sedimentation of CSF (cf. 1.c. (19)) e.g. in those diseases which are identified only by the qualitative alteration of cells.

CSF cytomorphology of primary and secondary CNS neoplasmas including leukemia and malignant lymphomas

\section{$K$. Jellinger and $R$. Weiss}

The overall accuracy of CSF cytodiagnosis in intracranial neoplasms ranges from 3 to over 60 percent with highest incidence in meningeal blastomatoses and solid metastases $(\sim 35 \%)$ as compared to less than $10 \%$ in isomorphic primary CNS-tumours. Non-specific monocytic CSF reaction is present in about $3 / 4$ of all intracranial tumours. Neoplastic cells in CSF cytograms may be found in patients with normal CSF cell count. In CNS involvement in acute leukemia and malignant lymphomas, presence of tumour cells is encountered in 70 to $95 \%$ of the cytograms performed, while the accuracy of CSF cytology in primary malignant lymphomas of the brain is about 45 percent. Therefore, CSF cytology represents an important method in the early diagnosis and therapy control of involvement of CNS in malignāncies and particularly in leukemia and malignant lymphomas. 


\section{Recommendations for the Investigation of CSF in Laboratory \\ Sample collection}

After discarding the first 5 drops of CSF $10 \mathrm{ml}$ are collected in one sterile transparent plastic tube (e.g. polystyrene, see page 508/509) with screw cap from adults and $5 \mathrm{ml} \mathrm{CSF}$ from children (minimum volume $3 \mathrm{ml}$ ). Cytological detection of CSF cells should be done with $2 \mathrm{ml}$ liquor within $2 \mathrm{~h}$. After $2 \mathrm{~h}$ fixation of CSF cells is necessary, e.g. with formaldehyde free of acid (e.g. from E. Merck, Darmstadt order No. 3999): $1.35 \mathrm{~mol} / \mathrm{l}$ final concentration. (The remaining CSF sample should be stored at $4^{\circ} \mathrm{C}$ for other analyses).

\section{Analysis of the sample}

The determination of at least 5 parameters have been recommended in the following scheme:

$1^{\text {st: }}$ appearance of CSF during collection if it is bright, sanguineous or xanthochrom. $2^{\text {nd. }}$ number of leucocytes corrected by the ery throcyte count (e.g. 1-2 leucocytes per 1000 ery throcytes); when $>5$ leucocytes per $\mu$ l are found, the CSF cells should be investigated after enrichment and staining (see pages 509/510); this is also the case with $<5$ leucocytes per $\mu l$ when the diagnosis of blastoma, multiple sclerosis, old injury, hemorrhage or encephaiitis are expected.

For the evaluation of blood brain barrier function the following steps should be carried out: $3^{\text {rd }}$ : total protein: semi-quantitative test may be done with the Pandy reaction; quantitative test with the biuret reaction after protein precipitation with phosphotungstic acid or trichloroacetic acid (cf. 1.c. $(22,23)$ ). The pattern of CSF proteins in electrophoresis with unconcentrated liquor, e.g. oligoclonal reaction (see page 508).

$4^{\text {th }}$ : albumin concentration should be determined in CSF and blood serum at the same time (cf. l.c. (11)); ratio of CSF albumin and serum albumin should be calculated.

$5^{\text {th }}$ : concentration of IgG should be determined in CSF and blood serum at the same time (see page 507/508), ratio of CSF IgG and serum IgG should be calculated to differentiate inflammatory processes from blood brain barrier disturbances.

$6^{\text {th }}$ : when one of the parameters in $3,4,5$ lies above the normal range for further information $\alpha_{2}$-macroglobulin, IgA and IgM can be determined in CSF and serum simultaneously.

Generally, serological investigations for syphilis and viruses should be done with blood serum taken in acute state and 2 to 4 weeks later. 5 to $10 \mathrm{ml}$ sterile CSF are needed for the detection of enterovirus, rubella virus, herpes virus, subacute sclerosing panencephalitis (24).

More meetings are needed to establish recommendations for optimum procedures for the determination of the parameters named above and regarding the other parameters discussed in this workshop further investigations are necessary.

\section{References}

1. Karcher, D., Zeman, W., Lowenthal, A. \& Chamoles, N. (1970) Brain Res. 17, 307-314

2. Bignami, A., Eng, L. F., Dahl, D. \& Uyeda, C. T. (1972) Brain Res. 43, 429-435

3. Müller, F., Kruska, M. \& Hippius, H. (1970), Z. Neurol. 198, 237-255

4. Müller, F. \& Ritter, G. (1978), Nervenarżt 49, 185-188

5. Felgenhauer, K., Schliep, G. \& Rapić, N. (1976), J. Neurol. Sci., 30, 113-128

6. Schliep, G., \& Felgenhauer, K. (1978) J. Neurol. 218, 77-86

7. Eickhơff, K. \& Heipertz, R. (1977), Clin. Chim. Acta 78, $343=349$

8. Eickhoff, K. \& Heipertz, R. (1978), Ann. Neurol. 3, 509512

9. Eickhoff, K., Heipertż, R. \& Wikström. J. (1978), Actạ Neurol Scand. 57, 385-395

10. Laurell, C. B. (197.2), Scand. J. Clin. Lab. Invest. 29, Suppl. $124,21-37$

11. Kleine, T. O. (1979) in Protides of the Biological Fluid. XXXVIth Colloquium (Peeters, H., ed.) Pergamon Press, Oxford, pp. 665-668

12. Kleine, T. O. \& Stroh, J. (1974), this journal 12, 73-80
13. Sieber, A. \& Schwick, H. G. (1978) Dtsch. Ges. f. Klin. Chemie Mitteilungen 1/78, 17-19.

14. Glasner, H. (1977) Klin. Wochenschr. 55, 181-187

15. Koppel, H. (1976) Wien. Med. Wochenschr. Suppl. 35

16. Lyman, D. J. (1974), Angew. Chem. 86, 145-150.

17. Christensen, P., Johansson, A. \& Nielsen, V. (1978) J. Immunol. Methods 23-28

18. Röschlau, P., Bernt, E. \& Gruber, W. (1974) this journal $12,403-407$

19. Sayk, J. (1974) in Handbook of Clinical Neùrology, North Holland Publ. Comp. Amsterdam

20. Kistler, G. S. \& Bischoff, A. (1963), Schweiz. Med. Wochenschr. 92, 863-866

21. Kleine, T. O., Flury, R. \& Tritschler, W. (1977), Dtsch. Med. Wochenschr. 102, 1216-1221

22. Richterich, R. \& Colombo, J. P. (1978), Klinische Chemie, Theorie, Praxis, Interpretation. S. Karger, Basel.

23. Kleine, T. O., Stroh, M. \& Stroh, J. (1974), this journal 12 $66-72$

24. Hsiung, G. D. (1973), Diagnostic Virology. Yale University Press, New Haven, pp. 3-4
Prof. Dr. T. O. Kleine Klin.-chem. Labor Universitäts-Nervenklinik Ortenbergstraße 8 D-3550 Marburg/Lahn 